\title{
The Upright Man: \\ Favorinus, his Statue, and the Audience that Brought it Low
}

\author{
ARTEMIS BROD \\ Indiana University
}

An Icon is a sign which refers to the Object that it denotes merely by virtue of characters of its own, and which it possesses, just the same, whether any such Object actually exists or not. It is true that unless there really is such an Object, the Icon does not act as a sign... 1

The expression "to be upright" has two connotations: first, to rise, to get up, and to stand on one's own feet and, second, the moral implication, not to stoop to anything, to be honest and just, to be true to friends in danger... We praise the upright man. ${ }^{2}$

\section{Orientation}

In the first epigraph, C.S. Peirce defines an icon in terms of its semiotic vulnerabilities. The defining feature of an icon is that it is in full possession of its signifying properties. None of those properties, in and of themselves, indicate their dependence on a referent (or, "Object"). The relationship between sign and referent, barring contextualizing markers that make the relationship explicit, is, there-

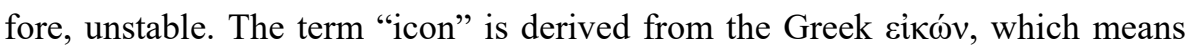
"likeness," and was, in the early Greek social context, used to refer to "portrait statues," images erected by decree of a polis in honor of an exceptional person. ${ }^{3}$

\footnotetext{
${ }^{1}$ Peirce [1940] 1955, 102.

${ }^{2}$ Straus 1966, 137.

${ }^{3}$ Lazzarini 1984-85, 89-90 notes that the first use of the term occurs on the statue base of

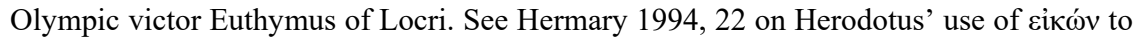


The word itself, then, indicates its dependence on a prototype. And yet, this only begs the question, who stands on the other side of this equation? What was the image a likeness of? ${ }^{4}$ The early Greek practice of erecting public statues demonstrates an awareness of the ambiguities inherent in the signifying properties of an

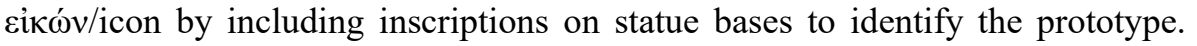
Surely, then, named and fixed in place, sikóveৎ achieved standing as icons of the honorand.

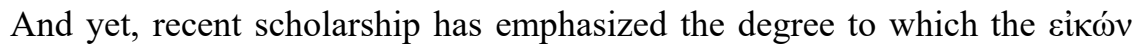
was a site of contestation. The earliest eikóvę were erected on the occasion of athletic victories. But, as Deborah Steiner puts it, "works commemorating realworld figures commissioned by the polis and placed in its communal spaces are not so much portrait likenesses, depictions of a body and personality unique to the single subject, as they are generic or idealized representations, which assimilate the specific to the broader type and the mortal to the heroic." If cikóveৎ were not reproductions of the uniqueness of an individual, then what did they re-present? Leslie Kurke, drawing on Joseph Day's work on funerary inscriptions, argues that

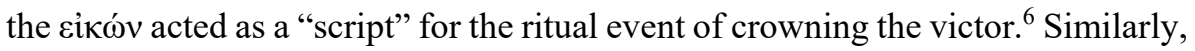
John Ma, writing about Hellenistic honorary portraits, argues that "the subject of the monument, and perhaps even of the statue, is not [the honorand], but 'the people has dedicated/honored [the honorand]', and the relation that is created by this transaction..."7 More radically, he argues, "[t]he honorific statue is... about the ontological primacy of community ... over individual." ${ }^{\prime 8}$ Thus, according to Ma, the political act of recognizing individuals was simultaneously an assertion of the polis' control and discretion over that very process.

refer to portraits of human subjects, and Keesling 2017, 41-43. Keesling 2017 argues that

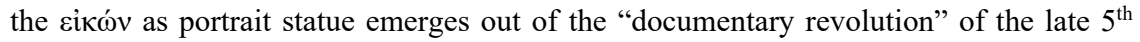
century BCE.

4 "Likeness" is a term that has been increasingly problematized. In her seminal study of Greek portraiture, Richter 1965 traces the "gradual evolution from a generalized likeness to an individual likeness" (1). But increasingly the evolutionary model of the emergence of physiognomic resemblance in Greek portraiture has been criticized. Dillon 2006 argues that "[c]hanging styles of portrait expression... were not simply the result of artistic innovation; they were developed in response to changing cultural demands...[P]ortrait does not simply represent the physical appearance of its subject ... portraits are more performative than they are descriptive" (99). See Keesling 2003, 167-169.

${ }^{5}$ Steiner 2001, 37. Cf. Lazzarini 1984/85, 88.

${ }^{6}$ Kurke 1998, 141-149.

${ }^{7}$ Ma 2013, 46-47.

${ }^{8}$ Ibid, 62. 
At the etymological root of Peirce's abstract concept, therefore, is a culturally embedded and politically fraught practice, which nevertheless prefigures the tension Peirce identifies in his definition. As a free-standing reproduction of a prototype, the eikóv/icon (threatens to) become(s) an independent object. Its relationship to the prototype can be forgotten or erased. Alternatively, it might be abused in the prototype's stead. In fact, all of these semiotic distortions were institutionalized under the Roman Empire. The less politically motivated practice involved the reuse of a statue: a city could dedicate a standing statue to a new honorand by reinscribing the base ( $\mu \varepsilon \tau \alpha \gamma \rho \alpha \varphi \eta$ ). The erasure of the name on a statue base might also be part of a broader effort to condemn an individual via damnatio memoriae. ${ }^{9}$ Statues might also be defaced, assaulted, or completely toppled, as a form of "surrogate corpse abuse." $" 10$

For the most part, victims of this sort of symbolic erasure or violence had little recourse - especially if they had been exiled or executed. But one defiant sophist of the second century CE, Favorinus of Arelate, whose statue was dismantled in Corinth, returned to the city to seek redress for the insult. ${ }^{11}$ Or, rather, he redressed the abuse himself. For Favorinus' strategy in this oration is to wrest semiotic control back from the polis. He does so by re-presenting himself as his statue (cikóv), as an icon of masculinity, and as the ultimate prototype ( $\pi \alpha \rho \alpha \dot{\delta} \varepsilon \varepsilon \gamma \mu \alpha)$.

Favorinus of Arelate was a well-educated, sexually indeterminate ${ }^{12}$ star sophist who wrangled with Polemo, was a friend of Plutarch, a favorite of Aulus

${ }^{9}$ A term that applies not only to the destruction of images and inscriptions, but also included the seizure of property and more. On the practice, see Stewart 2003, esp., 267-269, and Varner 2004.

${ }^{10}$ Kyle 1998, 183 n.106, quoted in Platt 2007, 264. Stewart 2003, 275-6 makes a stark distinction between toppling and mutilating statues, only the latter of which he argues operates according to the corpse analogy. But Favorinus compares the dismantling of his statue with corpse abuse in his Corinthian Oration.

${ }^{11}$ Barigazzi 1966, 301, following Norsa and Vitelli 1931, ix, n.7, dates the speech to 130 BCE. The date is speculative. It is based on the assumption that Favorinus was in fact exiled (see below) and that his exile was coincident with Polemo's ascension in the eyes of Hadrian. The date is ultimately determined by the choice of Polemo to give the address at the dedication of the Olympieion in Athens in 131. See Swain 1989 for doubts on this convenient chronology. It is possible that this speech was an exercise piece and not performed before a Corinthian audience (see, Schmid 1909). I assume that it was performed at Corinth throughout the article; but, even if it was not, the speech demonstrates the dexterity of Favorinus' performative imagination.

12 Philostratus calls him $\delta \varphi \varphi \theta n \varsigma$ ("of a double nature," "of a double sex”) and $\alpha v \delta \rho o ́ \theta \eta \lambda \nu \varsigma$ ("man-woman," "hermaphrodite") (VS 489). Polemo's description is more explicit: he is a "eunuch who is not a eunuch but who was born without testicles" (Leiden Polemo, A20, trans. Hoyland 2007). Mason 1979 ventures a precise diagnosis. Swain 2007, 4 calls him a cryptorchid. See also Holford-Strevens 2003, 99. 
Gellius, and Herodes' teacher. ${ }^{13} \mathrm{He}$ was also a student of Dio Chrysostom, who, perhaps a half of a century earlier, gave a speech of rebuke to the Rhodians for engaging overly much in the practice of $\mu \varepsilon \tau \alpha \gamma \rho \alpha \varphi \eta{ }^{14}$ Dio positions the Rhodians as the last bastion of Greekness and argues that by perverting the essentially Greek practice of honor-giving, they hasten the degeneration of Greek culture at large. ${ }^{15}$ Thus, he metonymically connects honor-giving to Greekness. Favorinus also relies on this metonymy to convey a sense of moral urgency to his audience. But the two orators offer distinct theories of the relationship between statue and prototype in their discourses. Dio argues that the statue is a possession of the honorand. ${ }^{16}$ Favorinus, on the other hand, concedes that the statue is the city's. ${ }^{17} \mathrm{He}$ does not appeal to material properties available to the concept of "likeness." $\mathrm{He}$ is all too aware that he and his statue depend on the audience and polis to grant or concede the significance to which he will lay claim. Instead, he insists that the ontological status of his statue is a matter - not of its materiality — but of his audience's experience of him as an exemplary model. In order to orchestrate this particular experience, Favorinus engages in a deliberate process of reorienting the audience towards himself.

Favorinus begins this process of reorientation early in the speech, when he first raises the issue of his statue's toppling. He reminds his audience why they erected his statue in the first place. Because they could not keep him, "instead,

${ }^{13}$ Philostratus records the friendship with Herodes and the rivalry with Polemo (VS 480-492). On Favorinus' biography see Lattanzi 1933, Barigazzi 1993, and Gleason 1995, with an emphasis on his rivalry with Polemo. On Gellius' favoritism, see Beall 2001. See Peuch 1992, 4850 for a brief synopsis of Favorinus' appearances in Plutarch and the contributions by Bowie 1997 and Opsomer 1997 in Plutarch and His World.

${ }^{14}$ On Dio Chrysostom as Favorinus' teacher see Philostr. VS 490, 492. Favorinus' oration comes down to us as part of Dio's corpus (= [Dio] Oration 37). On the historical context of Dio's Oration 31, see Jones 1978, 26-35. On the practice of $\mu \varepsilon \tau \alpha \gamma \rho \alpha \varphi \eta$ in Athens, see Shear 2007, Keesling 2003, 185-191. On the practice across the Empire, see Blanck 1969 and Keesling 2017, 182-216. On Dio and Favorinus' reaction to the practice, see Platt 2007.

15 31.157-169, esp. For honorary statues in the second sophistic, see Borg 2004 and Smith 1998. See Richter 1965, vol 3 for a survey of Greek portraits under the Roman Empire, including a possible statue of Polemo, identified as the sophist by Hekler because it was found at the Athenian Olympieion and "because the physiognomy corresponded with what is known of Polemon" (285). See also Bowie's very helpful table listing the professional associations of sophists with various cities, including their statues (2004, 76-82). Elsner 2007 postulates with respect to Favorinus' statue: "the most likely type was the himation with tunic, possibly in the so-called Aeschines posture..." (207).

${ }^{16}$ Dio 31.47. See Platt 2007, 261.

${ }^{17}$ In reference to his statue, Favorinus asks his audience: "Who overturned the city's dedica-

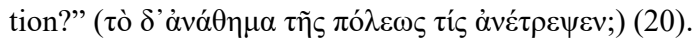




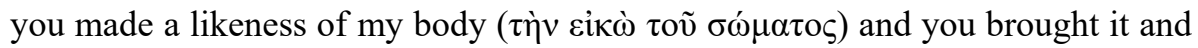
put it up ( $\alpha v \varepsilon \theta \eta \dot{\kappa} \kappa \alpha \varepsilon)$ in the library, in the front seat ( $\pi \rho \circ \varepsilon \delta \rho i ́ \alpha v)$, where you presumed that young men would be called upon to pursue the same work

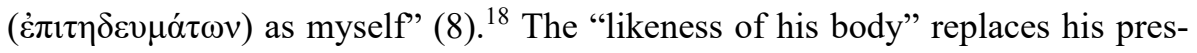
ence. ${ }^{19}$ But the sculpture is not there simply to be viewed. The goal is not to inspire passive admiration. The young viewer's admiration should be directed toward action. The statue was erected in (front of ${ }^{20}$ ) the library, Favorinus explains, for the specific purpose of inspiring people to pursue his noble profession. ${ }^{21}$ His statue and the library act together. The library reminds viewers of all that Favorinus embodies (his paideia) and his statue directs them to the library so that they might achieve a similar station. His statue's identity, therefore, is contingent on his

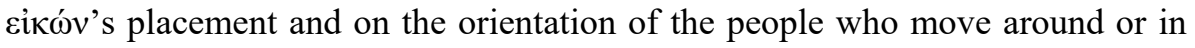
front of it.

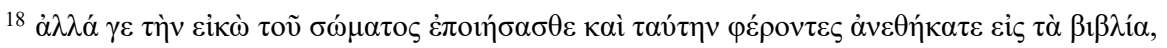

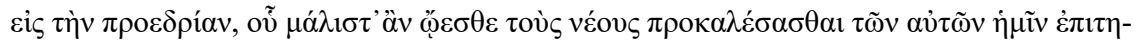

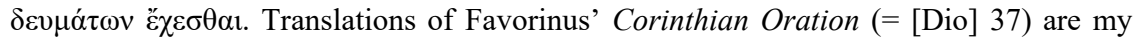
own; I use von Arnim's text (1898).

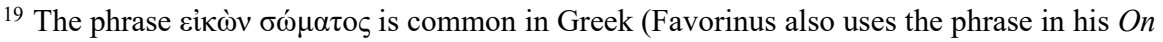

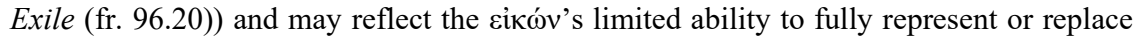
the person depicted. As Platt 2011 writes, "While eikōn suggests a close relationship between image and prototype...it nevertheless involves an element of ambiguity, implying representation, shadow, seeming, rather than the 'thing itself"' (204). Likewise, the word $\sigma \tilde{\omega} \mu \alpha$, as Brooke Holmes has shown, implies "the tension ... between the integrity of the person and the collapse into formlessness at death" $(2010,36)$. As such, it "can act both as a unifying term and as a foil to the person" $(2010,21)$. Each term in the expression cikòv $\sigma \omega ́ \mu \alpha \tau \zeta$, then, connotes the object's potential failure. It is a commonplace in the study of Greek portraiture to point out that the body is "just as if not more important than the head and face" (Dillon, 2006, 76). Breckenridge 1968 calls the Greeks "almost perverse in [their] refusal to acknowledge that the head...deserves special emphasis" (10). But this

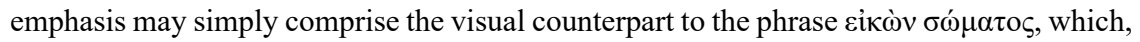
as a foil to the prototype, conveys its own limits in order to better suggest the latter's integrity.

${ }^{20}$ White $2005,74-77$ argues that the statue stood in the forum outside of the library, and, moreover, that this was the site of Favorinus' performance. In my reading of the final section of his speech, I will follow this suggestion, although the statue could just as easily have stood within the library (for example, in a niche, like those that lined the Celsus library).

${ }^{21}$ Dio 31.21 argues men perform exceptional deeds in order to gain honors, not least of which is being set up in bronze. Cf. Nodelman 1975, who, elaborating on the Latin word signum, writes, "the will to reach out actively into the world of on-going life and to accomplish specific purposes within it through psychological modifications imposed upon the observer is the central organizational principle of Roman art" (27). See Amato 2005 ad loc for discussion of an epigraphical example of the same notion. 
This speech has become a locus classicus for the discussion of Greek identity under the Roman Empire. Maud Gleason and Tim Whitmarsh situate Favorinus' posturing within the larger culture of agonistic self-representation. While Gleason focuses on the construction of gender and Whitmarsh on the construction of literary identities, both emphasize Favorinus' claims regarding the transformative (and transcendent) effects of paideia. ${ }^{22}$ Other scholars have homed in on the Corinthian setting as a foil for Favorinus' self-presentation. ${ }^{23}$ Jason König, for example, argues not only that Favorinus mocks the Corinthians for their disloyalty to their Greek heritage, but that he "humorously acknowledges the possibility that his own acquired Hellenism may be implicated in the insufficiencies for which he criticizes his audience." ${ }^{24}$ Michael White vividly imagines that the speech was performed in the Corinthian forum and connects mythological references within the speech to monuments that would have been visible. ${ }^{25}$

I follow the work of these scholars by focusing on how Favorinus constructs and negotiates his identity vis-à-vis his audience and other orators active at the time. But I do so by performing a rhetorical analysis of Favorinus' language of orientation. My interpretation is inspired by Sara Ahmed's Queer Phenomenol$o g y$, which "aims to show how bodies are gendered, sexualized and raced by how they extend into space." ${ }^{26}$ Ahmed argues that orientation "is about making the strange familiar through the extension of bodies into space;" "disorientation," therefore, "occurs when that extension fails." ${ }^{27}$ Favorinus describes the removal of his statue as disorienting: it destabilizes his relationship to his audience and, as he reports, to reality itself. It is as if its destruction threw the ontological status of the image's prototype into question: "Does he (the Object) actually exist, or not?" To answer this question, Favorinus establishes a relationship with his audience by

${ }^{22}$ Gleason 1995 and Whitmarsh 2001. Gender is also crucial to Whitmarsh's discussion 2001, 109-116, but he argues that Favorinus' literary hybridity trumped the demands of performing an "uncompromised virility" in his self-fashioning (115, cf. 168). On paideia as transcendent, see Gleason 1995, 167-8.

${ }^{23}$ In addition to the articles cited below, see Whitmarsh 2001,121 and Goeken 2005. Højte 2002 argues that Corinth became the "new center" for erecting statues in the second century CE - a tradition which seems to have lasted into the $4^{\text {th }}$ and $5^{\text {th }}$ centuries (see, Brown 2012).

${ }^{24}$ König 2001, 142.

${ }^{25}$ White 2003 and 2005, who also offers a rhetorical analysis of the way Favorinus uses legal punning when describing actions performed on his statue.

26 Ahmed 2006, 5.

${ }^{27}$ Ibid. 11. I do not have the space to fully treat Ahmed's arguments and their relevance to this speech here. A fuller treatment would grapple with the degree to which Favorinus' self-presentation undermines or reinforces norms of Greek elite masculinity. See, for example, Vitanza 2005, who argues that Favorinus "is ever becoming a third figure, or sex" (160, italics original). I plan to address this issue further in my book in progress. 
grounding their interaction in space and by making himself an extension of their perceptive work. Ultimately, this will lead to his adoption of an "upright" (ópӨós) posture. Taking full advantage of the metaphorical nature of spatial language, ${ }^{28}$ Favorinus participates in what Victoria Rimell, following Adriana Cavarero, has recently called the "gendered ontology of rectitude." ${ }^{29}$ With his upright posture, Favorinus will demonstrate, not only that he exists, but that he exists as a paradigmatic Greek man.

\section{The Unnamed Charges: The Man who does not Walk Upright}

Favorinus projects manliness in response to two interrelated imputations against him. The more general imputation questioned whether he was a man at all. The more specific and (perhaps paradoxically to a modern reader) concomitant involved a charge of adultery. ${ }^{30}$ Favorinus seems to address the latter in his speech to the Corinthians (33-36) and because Favorinus was accused of adultery by a man of consular rank, it is often assumed that his statue in Corinth (and perhaps also in Athens) was removed because of these accusations. ${ }^{31}$

${ }^{28}$ On the inherently metaphorical nature of language, see Lakoff and Johnson 1980.

${ }^{29}$ Rimell 2017, 771. I am grateful to the reviewer who directed me to this reference. Rimell argues that, in his Epistles, Seneca "reconfigures rectitude as a striving for equilibrium ..." (773) by "alter[ing] our perception of inclination as necessarily 'feminized', perverse, or weak, while at the same time figuring virtuous rectitude in terms of ... flexibility, care, affection, and responsibility" (775). If, as Ahmed 2006 demonstrates, becoming orientated requires work, Cavarero 2016 traces the work the philosophical tradition has done to naturalize rectitude (by associating standing upright with rational thinking and the divine) and attempts to transform this ideally independent subjectivity by "inclin[ing] it...bending it, giving it a different posture" (11). She interrogates orthos and orthotēs in Plato and in Heidegger's reception of Plato's allegory of the cave. On associations between rectitude and the divine, see Rimell on Virtue $(2017,772)$, Cavarero on Adam (2016, 57-64) (Cf. Ahuvia Zornberg 1995, 20-24, who discusses how Adam's upright posture prompts all other animals to mistake him for their creator) and O'Sullivan (2016) on Apuleius' fictionalization of Platonic theory. Interestingly, Aulus Gellius quotes Favorinus in his note on Socrates' physical training, which consisted of standing up straight for a full twenty-four

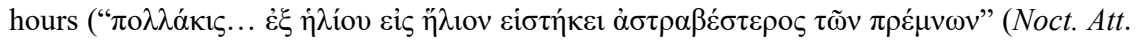
2.1.3)).

${ }^{30}$ Philostratus VS 489 tells us that Favorinus was "so ardent in love that he was actually charged with adultery by a man of consular rank" (trans., Wright 1921). On the Roman depiction of eunuchs as excessively sexual, see Stevenson 1995, 499-504. Stories and stereotypes about eunuchs as adulterous were common. See, Luc. Eun., Juv. 6.366-378, Mart. 6.2 .

31 There are other possibilities: Philostratus VS 490 tells us that Favorinus and "the Emperor" had a falling out over the sophist-philosopher's appeal for immunity when he was 
Whether or not Favorinus was directly addressing the adultery charge, the speech must be read, as Gleason has shown, as an agonistic response to the kind of abuse Favorinus incurred from rival sophist Polemo. ${ }^{32}$ Philostratus laments the vitriolic nature of their rivalry ${ }^{33}$ and Polemo's characterization of the "eunuch who is not a eunuch but who was born without testicles" 34 in his Physiognomy, makes clear why: ${ }^{35}$

appointed $\alpha \rho \chi 1 \varepsilon \rho \varepsilon v ́ \varsigma$ (the flaminate of the Narbonensian concilium (Bowersock 1969, 35)). Cassius Dio also gives an account of the immunity dispute (69.3-4). Favorinus' identity as a philosopher was the grounds for his immunity petition (Philostratus includes him in his discussion of philosophers who had reputations as sophists (VS 492); on the substance of his philosophy, see Ioppolo 1993 and Holford-Strevens 1997). A related problem is Favorinus' exile. His speech On Exile suggests that he was banished, but reports on the conflict with Hadrian make no mention of any such punishment. As we saw above, Favorinus boasts that he quarreled with an emperor and lived and Philostratus says that "he suffered nothing" (ov̉ $\dot{\varepsilon} v$ है $\pi \alpha \theta \varepsilon v$ ) (489) in the dispute. Cassius Dio (69.3-4) also reports that nothing came of the squabble. Amato 2000 argues that the exile was real. Holford-Strevens 2003, 102 agrees. Swain 1989, Fein 1994, and Nesselrath 2006 remain doubtful. Whitmarsh reads Favorinus' On Exile as primarily an act of literary self-representation and identification. The trope of exile was employed by writers who "saw themselves as outsiders and late comers to Greek language and culture" $(2001,179)$. For fuller discussions teasing out the various possible connections between the adultery charges, the impunity dispute and the removal of Favorinus' statues, see Swain 1989 and Holford-Strevens' challenges thereof $(1997,2003)$.

${ }^{32}$ Gleason 1995, 7. And the insults meant to police the boundaries of sophistic and philosophical performance as depicted in Lucian's Eunuchus and Demonax. In the latter, the eponymous philosopher insists on his right to act as gatekeeper against Favorinus'

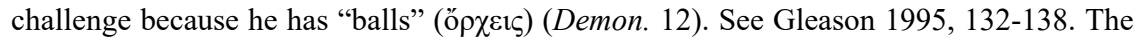
speech, therefore, furthermore represents, as Gunderson writes of Quintilian's "technology of the self," "a site of labour designed to secure masculine being" against claims that Favorinus' project of self-presentation has "failed," is incomplete, and "queer" (Gunderson 1998, 189). On Favorinus" "incomplete" body, see below.

${ }^{33}$ VS 490-491. See also VS 536, where Polemo defends himself to his teacher Timocrates for his speeches against Favorinus. As König 2011, 287 writes, for Philostratus, "striving individually for glory...is acceptable, but not when it turns into ad hominem bellicosity."

${ }^{34}$ Leiden Polemo, A20, trans. Hoyland 2007.

35 The original Physiognomy is lost. There are two Arabic versions: the Leiden Polemo and a work that rewrites the original Arabic version (also lost), the Istanbul Polemo; additionally, there is a Latin text that purports to be a compilation of Loxus, Aristotle, and Polemo, but seems mostly taken from Polemo. Finally, a Greek epitome of Polemo's Physiognomy was written by one Adamantius, which did not include Polemo's individual character portraits. See Swain 2007, 2-6 for discussion. These texts were originally compiled and edited by Förster 1893. I use the edition edited by Swain 2007, which includes cross-references. Repath 2007a for the text and translation of the Adamantius text (Ad.), and 2007a, 487 on the writer's identity; Repath 2007b on the Anonymous Latin (Anon. Lat.). 
He was greedy and immoral beyond all description... His neck was similar to the neck of a woman, and likewise the rest of his limbs, and all his extremities were moist, and he would not walk erect, and his limbs and members were flaccid...(He would give in) to every cause that incited a passion for desire and sexual intercourse. He had a voice resembling the voice of a woman and slim lips...He had learned the Greek language and its discourse by virtue of speaking a great deal, and he was called a sophist... ${ }^{36}$

Polemo goes so far as to call him a murderer and he follows his sketch of Favorinus with a chapter on eunuchs who are indeed "evil," but, he explains, "no one is more perfect in evil than those who are born without testicles." ${ }^{37}$ Favorinus, then, occupies the polar end of the morally degenerate spectrum. ${ }^{38}$ His undisciplined body is metonymically inextricable from his moral decrepitude.

Polemo, who is deemed a paragon of masculinity by Herodes, ${ }^{39}$ marshals standard tropes of femininity against Favorinus - all related to the softness, moistness, and looseness of the body. ${ }^{40}$ Moreover, the material constitution of his body affected his gait: he does not walk upright. ${ }^{41}$ And straightness clearly increased the measure of a man - especially a Greek man. Adamantius, for example, employs the adjective ó $\rho \theta$ ó $\varsigma$ or ó $\rho \theta$ to $\_$- "straight," "upright"- three times in his description of "Greek appearance" ( $\varepsilon \tilde{i} \delta \circ \varsigma^{\prime}$ E $\left.\lambda \lambda \eta v i \kappa o v ̃\right)$. Those who have kept the race

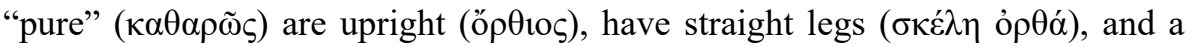
straight nose ( $\dot{\rho} \tilde{v} \alpha \alpha \dot{o} \rho \theta \eta \dot{v}) .{ }^{42}$ An upright posture is the defining feature of a "manly

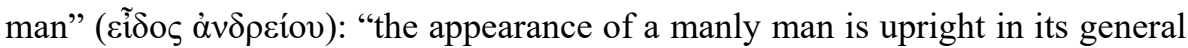

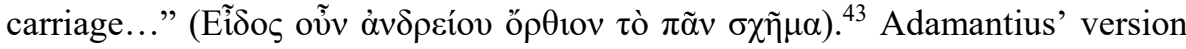
also includes an interesting comment on androgyny in a section on the neck. For some with a motionless neck, he explains, the quality is a sign of stupidity. But "others with motionless necks steer themselves and strive artificially and with

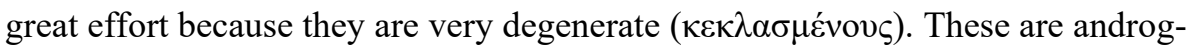

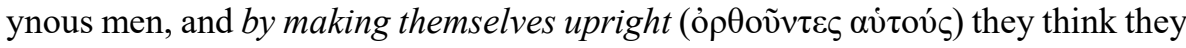

${ }^{36}$ Leiden Polemo, A20, trans. Hoyland 2007.

${ }^{37}$ Leiden Polemo B3, trans. Hoyland (=Ad. B3).

${ }^{38}$ See Gleason 1995, 47.

${ }^{39}$ According to Philostratus VS 539, Herodes once declared: "Read the declamation of Polemo and you will know a man."

${ }^{40}$ Cf. Anon. Lat. 40 (= Leiden Polemo A20). Gleason 1995, 7, 46-48 on Polemo's sketch of Favorinus. More generally on the semiotics of gender in his Physignomy, Gleason 1995, 46-81. See also, Barton 1994, 115-118.

${ }^{41}$ See Swain 2007, 185-192 on movement and gender in the Physiognomy and Gleason 1995, 60-62 on "walk[ing] like a man."

${ }^{42}$ Ad. B32, trans. Repath 2007.

${ }^{43}$ Ibid, B44. An upright body also characterizes the "talented" man (દủpvís) (B46). 
hide their lewdness." ${ }^{\text {"4 }}$ Although he is not talking about eunuchs (or men born without testicles) here, Adamantius is talking about effeminate men and Polemo, as we saw above, characterizes Favorinus as feminine (making special mention of his neck!).

Favorinus was appropriately devious in his "response" to this kind of invective. He famously boasted of having lived a life of three paradoxes: he was "a Gaul who spoke Greek, a eunuch tried for adultery, and having argued with an Emperor, he lived." ${ }^{25}$ In sum, he is a man who eschews the grasp of otherswhether that grasp be cognitive or punitive. If he had sex when he should not have, he did so as a eunuch. If he mastered the Greek language, he did so without native advantage. And if he lives under an empire, he does so in open defiance of its head of state.

In fact, Favorinus seems to have spent his career challenging the idea that identity is intrinsically linked to one's origins - biological or geographical. ${ }^{46} \mathrm{In}$ this oration, he makes the case that his identity is all the more "real" for being constructed, precisely because it is the product of his intentional desire. It follows, then, the logic of the first two paradoxes. If Polemo is right and Favorinus had a penis but did not have testicles, then his sexual desire was not determined by the biological function of copulation - namely, to emit semen and reproduce. Likewise, his Greekness is not the product of Greek blood, but of his work. Therefore, his desire - sexual, identificatory—is purer-paradoxically more authenticthan those whose bodies define their pursuits. It is a product of his willful inclinations. Favorinus responds to invective that a slouching posture indexes an imperfect masculinity, ${ }^{47}$ therefore, precisely by "making himself upright."

In what follows, I trace Favorinus' argument in three sections. The first part of the oration (1-22) describes his disorientation. In the second section (22-37), Favorinus introduces the conceit of a trial. In his attempt to re-establish his sense of reality he considers why his statue may have been taken down and he imbues the

${ }^{44} \mathrm{Ibid}, \mathrm{B} 21$. The inclination of the neck (to the left) is also a repeated index of femininity. I do not have the space here to treat vocabulary related to "inclination" qua deviance here, but it is pervasive.

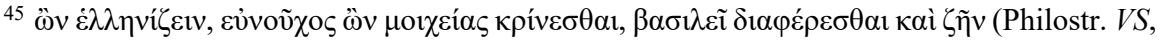
489).

${ }^{46}$ In his On Exile, for example, Favorinus asserts that one's fatherland is a matter of choice; alternatively, autochthony is a characteristic of animals (10). Citizenship is granted by the $\gamma v \omega ́ \mu \eta$ of the people (14). Humans are by nature transient (15.2). See Whitmarsh 2001, 167-180 and Gleason 1995, 147-158.

${ }^{47}$ In Lucian's Eunuchus, Stoic and Cynic philosophers insult the eunuch philosopher (prob-

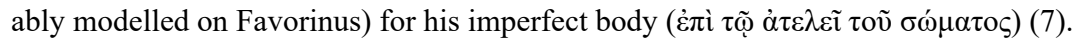


audience's spectatorship with juridical force. It is in this section that Favorinus establishes himself as a product of his audience's orientation toward him. The third section (38-47) is concerned with the reconstitution of the relationship between himself, his statue, and his audience. Favorinus rejects any ontological claim the statue may have on him, and, in the final gestures of the speech, he performs its resurrection by subsuming it into his own posture.

\section{Disorientation}

After the exordium, Favorinus appeals to the audience's sympathy by explaining

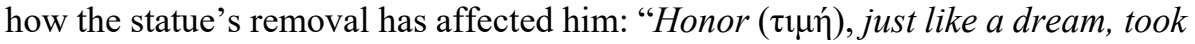

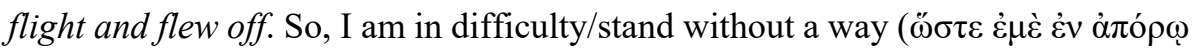
$\kappa \alpha \theta \varepsilon \sigma \tau \alpha \dot{v} \alpha$ l), both with respect to myself, and now, by God, even with respect to others, as to whether I truly did not see a real vision, but the things that happened were a dream" (9). ${ }^{48}$

In the Homeric line that opens the quote, Favorinus has replaced "soul" ( $\psi v \chi \eta ์)$ with "honor" $(\tau \mu \mu \eta) .{ }^{49} \psi v \chi \eta$ and $\tau \mu \mu \eta$ define the extent- the limit and the range — of one's life. $\tau \mu$ í extends an individual's life beyond their body, by expanding both their physical and temporal reach. If, as Vernant has put it, "one of the functions of the human body is that it precisely positions every individual, assigning him one and only one location in space," a touchstone marking the various places where an individual's impact has been felt. ${ }^{51}$ Reading Favorinus' claim literally ("I stand without a way"), we see that the loss of one of these touchstones has disrupted Favorinus' sense of how to move forward and, thus, of what is real. He is physically disoriented by the dismantling of his statue. ${ }^{52}$

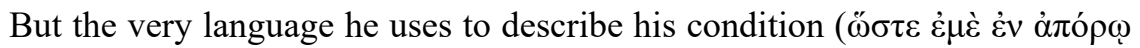
$\kappa \alpha \theta \varepsilon \sigma \tau \tau^{\prime} v \alpha$ ) will provide the basis for a rhetorical path forward, as his words take on performative force. $\kappa \alpha \theta i ́ \sigma \tau \eta \mu 1$, which can mean "to erect" and (in the perfect) "to be set, to stand, to become," captures both Favorinus' mental state and his

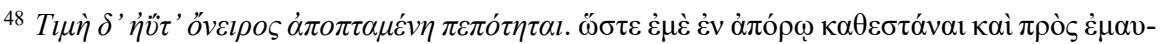

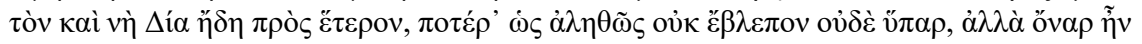

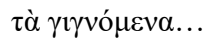

${ }^{49}$ Hom. Od. 11.222.

${ }^{50}$ Vernant 1989, 39.

${ }^{51}$ Favorinus also had a statue in Athens, which was also removed (Philostr. VS 490).

${ }^{52}$ Cf. White who attributes Favorinus' "'emotional state' of perplexity” to the Corinthians' "breach of the obligations of friendship" $(2003,320)$. 
statue's (would-be) physical state. ${ }^{53}$ For Favorinus, the connection between being "set up," "standing," and "becoming" is causally linked by the semantic range of the verb: to become reoriented with respect to reality is to be set down before his audience, which begins with his standing before them. But the work will ultimately be completed by the audience. After a short mythological narrative establishing the city's divine favor (12-15), Favorinus expresses surprise that a city with as prestigious a past as Corinth's would have condemned his statue without a trial (16). He gives a brief history of the city's heroic interventions, repeating

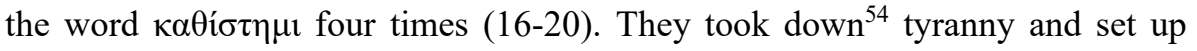

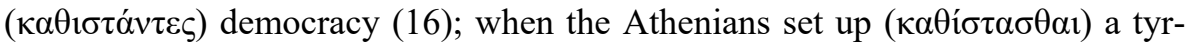
anny, they (the Corinthians) became ( $\left.\kappa \alpha \alpha \sigma \tau \tau^{\prime} v \tau \varepsilon \zeta\right)$ leaders of freedom; at Sala-

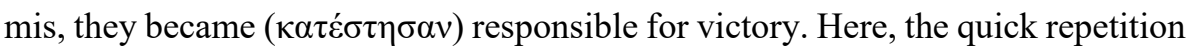
of $\kappa \alpha \tau \alpha$-prefix verbs reminds the audience of their power. If they can put up democracies, surely they can restore his statue - and with it, his reality. Their past provides a way back to the here and now.

\section{The Trial}

As Favorinus pivots to a performative use of language, he simultaneously imbues his audience's attention with juridical (and thus performative) force, by introducing the conceit of a trial. A successful outcome will accomplish the statue's acquittal, its resurrection, and the restoration of the Greek practice of honor-giving - all while sustaining the democratic institution of the trial.

Favorinus introduces the trial with a question: "Who overturned the city's

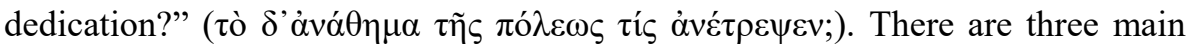

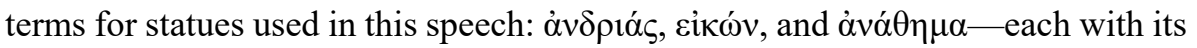

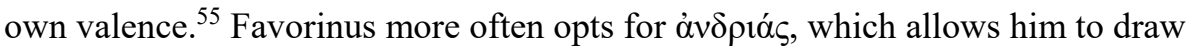
a verbal connection between his honor and his manhood. ${ }^{56}$ But àvoptá $\varsigma$ does not

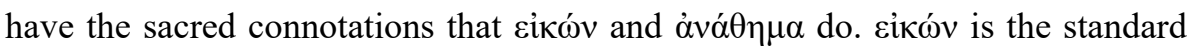
term for an honorary portrait statue and, as Gleason notes, it is Dio Chrysostom's default term in his Rhodian Oration. Eikóves are sacred insofar as they recognize a benefactor as mediating between a polis and a god. As Ma explains, in dedicatory inscriptions, the verb $\dot{\alpha} v \alpha \tau i \theta \eta \mu$, "frames the act of setting up the statue as a

\footnotetext{
${ }^{53} L S J$ s.v. A.I.1, B.I.1, B.I.1b, B.I.5.

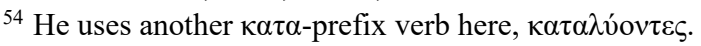

${ }^{55}$ For a full list of terms used, see Amato 2005, 421.

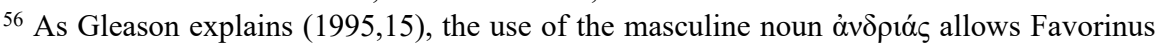
to amplify the ambiguity between himself and his statue when employing pronouns and demonstrative adjectives.
} 
permanent gift to a god or gods...recorded in permanent writing - a religious act." ${ }^{27}$ Thus, "the honorand is caught as the middle term within a relation of verticality where the exchange between the community and benefactor is enclosed within the gesture of homage and offering between community and divinity." 58 If the verb $\dot{\alpha} v \alpha \tau i \theta \eta \mu$ defines the act of dedication as sacred, the noun, $\dot{\alpha} v \alpha \dot{\theta} \theta \eta \mu \alpha$, "votive offering," fully embodies that sanctity. ${ }^{59}$ In the case of $\alpha v \alpha \theta \eta \dot{\eta} \mu \alpha \tau \alpha$, there is no benefactor who mediates between city and god; the offering of thanks recognizes a direct benefit. And the object is defined explicitly as something with an

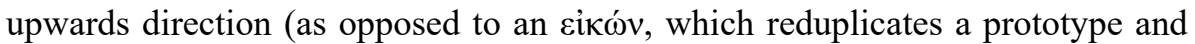
therefore exists on the same plane). ${ }^{60}$ The framing question of the trial includes the first of two instances in which Favorinus uses $\alpha \dot{\alpha} \alpha \dot{\theta} \eta \mu \alpha$ to refer to his statue, and the placement is structurally significant. Here, he describes the statue's dismantling and the question aurally reproduces the destabilization Favorinus and

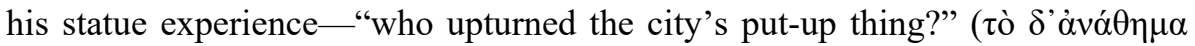

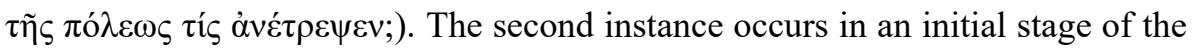
statue's performative resurrection. But, by then, Favorinus will have justified the use of the term by establishing himself as a product of divine will.

Favorinus begins his embedded trial speech with an appeal to the audience to accept the terms of the performance: "allow me, allow that I might to make a speech on his behalf ( $\dot{v} \pi \dot{\varepsilon} \rho \alpha \hat{v} \tau o \tilde{v}^{61}$ ) before you as if in a court of law (oĩov $\dot{\varepsilon} v$

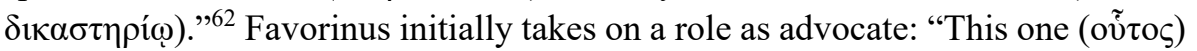
risks, in short time, to be set up as the best of the Greeks but then to be cast aside as the most despicable" (22) ${ }^{63}$ But, in the next period, the speaker states, "About

${ }^{57}$ Ma 2013, 26.

${ }^{58}$ Ibid, 46.

${ }^{59} \dot{\alpha} v \alpha \theta \eta \dot{\mu} \mu \alpha \tau \alpha$ need not be statues, but might be statues of the gods (Keesling 2003 argues that the famous Athenian korai statues portray Athena, for example). See Platt 2011, 77-123 for discussion of divine images. For discussion of other kinds of votive offerings, see van Straten 1992.

${ }^{60}$ Lazzarini emphasizes the use of the verb $\alpha \nu \alpha \tau i \theta \eta \mu$ to mark "una differenza di livello, di piano, fra il dedicante e la divinità ricettrice dell'offerta," contrasting its use with $\delta$ í $\delta \omega \mu$, which "sottintende un percorso dell'oggetto in linea orizzontale" (1989-1990, 845-846). As Keesling 2003, 3 notes, "[c]alling votive dedications $\alpha \dot{v} \alpha \theta \eta \dot{\eta} \mu \alpha \tau \alpha$ emphasized the physical and conceptual elevation of gifts for the gods above the normal spheres of human interaction and commerce." According to Keesling ibid, 165-198, honorific statues differ from $\dot{\alpha} v \alpha \theta \eta \dot{\eta} \mu \alpha \tau \alpha$ insofar as the former "represent human subjects... and [their] inscriptions always include the name of the person represented" (167). See also Keesling 2017, 47-48.

${ }^{61}$ Here (as at 27), following Gleason 1995, 13, I retain the ms. reading rather than adopting proposed emendations (Crobsy and Barigazzi read aṽoṽ).

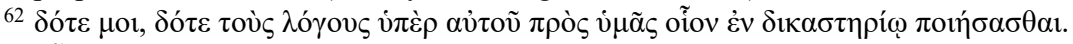

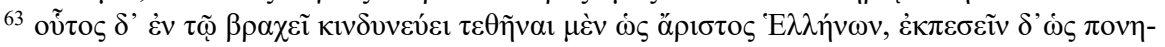

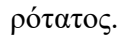


the fact that fairly and justly and beneficially for your city and all of Greece I was set up ( $\left.\dot{\varepsilon} \sigma \tau \dot{\alpha} \theta \eta v^{64}\right)$, I have a lot to say, but I would like to describe what happened in Syracuse" (23). ${ }^{65}$ Now, instead of the advocate, the statue seems to speak. ${ }^{66}$ This is the first of two instances in which Favorinus pronounces, $\dot{\varepsilon} \sigma \tau \dot{\alpha} \theta \eta v$. Like his use of $\dot{\alpha} v \alpha \dot{\theta} \theta \eta \mu \alpha$, these instances $(23,27)$ enclose the most famous section of the speech, wherein he boldly claims to embody paradigmatic Greekness; they stand as pillars on either end of an excursus on his exemplarity. I read these two assertions, then, as breaks in the framing narrative of the trial. Rather than an oggetto parlante, this word is spoken by Favorinus himself. According to Ma, inscriptions on statue bases that evade deictics referring to their statues represent what it is that images do: "they confront the viewer with a presence which is also an absence. ${ }^{967}$ By breaking out of character, Favorinus reasserts his presence, the reality of the original "Object."

Favorinus' famous claim is embedded in a foil: he relates the story of a Lucanian who, on embassy to Syracuse, spoke Doric. He suggests to the Corinthians that they model their reception of him (Favorinus) on the behavior of their former colony, Syracuse. The Syracusans took such pleasure in the Lucanian's voice

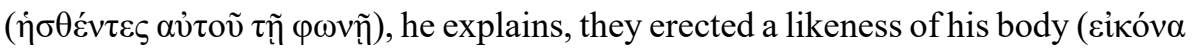

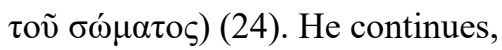

And let's say he's not a Lucanian, but a Roman, and not one of the many but an eques, and one who strives zealously, not only for the voice alone, but also

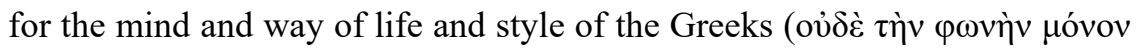

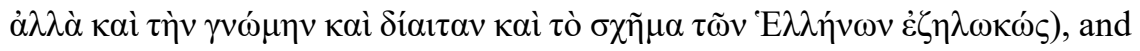
so masterfully and notably at that, that neither of Romans living before him,

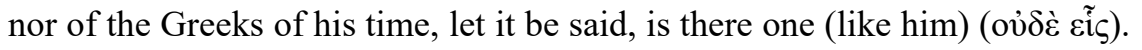
For of the Greeks it is possible to see their best over there inclining toward Roman things, but the guardian inclines toward Greek things, and on account of this, he relinquishes his property and political position and absolutely everything, so that there might be left to him one thing instead of all else, to seem

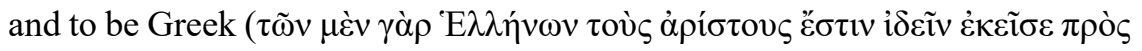

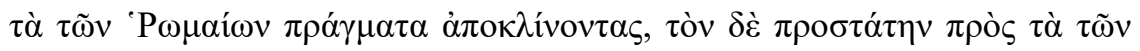

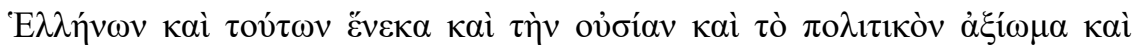

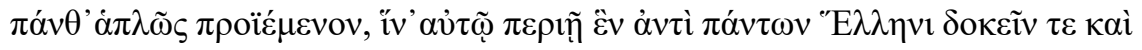

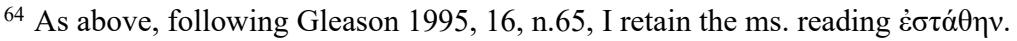

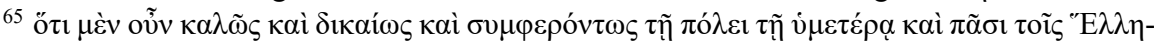

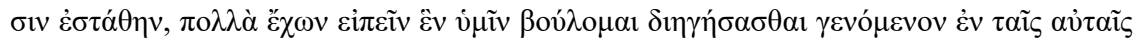

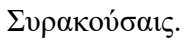

${ }^{66}$ See Amato 2005, 112 and Gleason 1995, 16.

$672013,28$.
} 


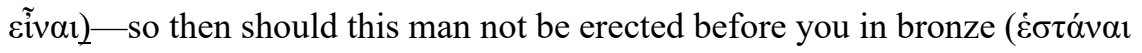

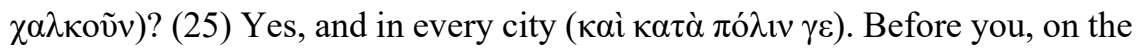
one hand, because as a Roman, he was Hellenized, as was your city; before the Athenians, because he Atticizes; before the Spartans, because he's a lover of exercise; and before everyone because he philosophizes and he has already persuaded many Greeks to philosophize with him and he has attracted not a few barbarians. (26) Indeed, for this very thing, it seems, he was made by the

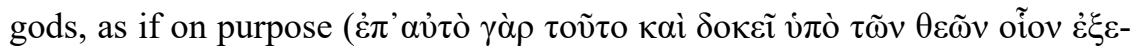
$\pi i \tau \eta \delta \varepsilon \varsigma \kappa \alpha \tau \alpha \sigma \kappa \varepsilon v \alpha \dot{\sigma} \sigma \theta \alpha)$, for the Greeks on the one hand, so that natives of Greece might have a model that there is no difference between being educated

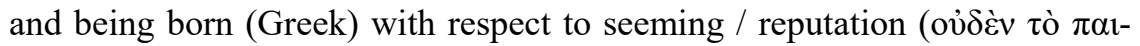

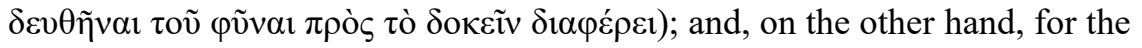
Romans so that coveting personal honor, they do not overlook ( $\pi \alpha \rho \circ \rho \tilde{\omega} \sigma \mathrm{l})$ education with respect to honor; and for the Celts so that not one of the bar-

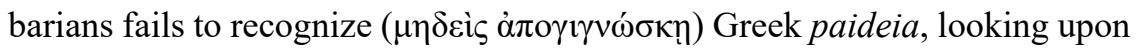

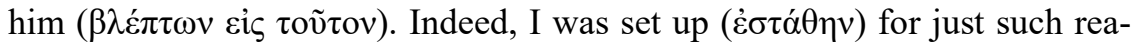
sons... (27)

This passage reiterates Favorinus' exceptionalism in four periods of antithesis and amplification. What begins as a foil contrasting two individuals - the Lucanian and a hypothetical man deserving of a statue (himself) - becomes an assertion of the man's singularity with respect to all Greeks and Romans. In this passage, as we will see, Favorinus slowly emerges from the rhetorical foil (and the foil of the

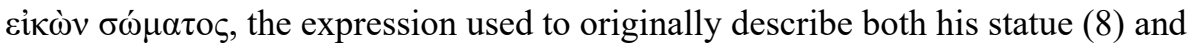
the Lucanian's $\left.(24)^{68}\right)$ to declare, once again in the first person, "I was set up"

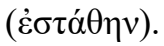

In the first period, Favorinus argues for his singularity using a rhetoric of exceptionalism: there is no one (but him); and nothing left (to him) but his Greekness. In the second period, he begins to explain how the hypothetical man has achieved this identity. His singular status is a product of his inclination, the objects towards which he tends - in other words, his orientation. And the objects towards which he tends are Greek: he wants to embody Greekness in voice, mind, way of life, and style. Because he was not born a Greek he begins farther away from his object. And while the best of the Greeks incline (away from their Greekness and) toward a Roman way of life, he works - through his intention and effort-toward Greekness. Rhetorically, Favorinus represents this contrast by stretching out the clause describing the Greek inclination towards Roman things ( $\tau \tilde{\omega} v \mu \bar{\varepsilon} v$ yò $\rho$

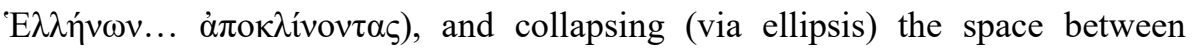

${ }^{68}$ On the expression as a foil see discussion in note 19 above. 


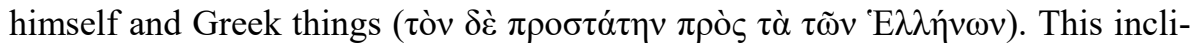
nation is singular in its focus: he abandons "absolutely everything" to it. These first two periods, therefore, revolve around the word "one." Favorinus is singular

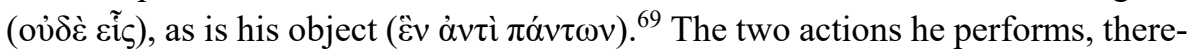
fore-tending toward and letting go-isolate two entities, subject and object. When the line between them is drawn, he comes to embody the object towards which he has exerted himself, "to seem and to be Greek."70

The singularity for which he argues anticipates its sign — the statue ("should this man not be erected before you in bronze?"). But so does his vocabulary. Von Arnim posited that $\pi \rho 0 \sigma \tau \dot{\alpha} \tau \eta\rceil$ sas a dittographical error with $\pi \rho \grave{\varsigma} \varsigma \tau \grave{\alpha} \tau \tilde{\omega} v .^{71}$ But the homophony equates his "standing before" the audience with his orientation towards all things Greek. His physical presence before the audience allows him to perform his role of protector ( $\pi \rho 0 \sigma \tau \alpha \dot{\tau} \tau \eta \varsigma$ ) of Greekness. The alliteration layers the concepts precisely, the one over the other-two iterations of the same beat. Moreover, $\pi \rho 0 \sigma \tau \alpha \dot{\tau} \tau\rceil \varsigma$ was part of the rhetoric of honorary inscriptions. Puech includes two instances in her compilation of inscriptions relating to Imperial Greek orators. $^{72}$ One inscription from Corinth dating to the second century CE calls its dedicand a friend ${ }^{73}$ and $\pi \rho 0 \sigma \tau \alpha \dot{\tau} \eta \varsigma$ on account of his $\alpha \rho \varepsilon \tau \eta$ and $\pi i \sigma \tau \iota \varsigma .{ }^{74}$ Even if the word was not used in the inscription on his own base, Favorinus might be harnessing the limited available epigraphical terminology to trigger the resurrec-

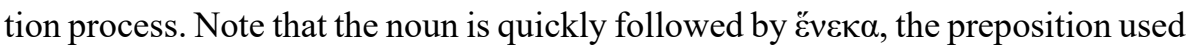
ubiquitously to introduce the justification of the honor on a statue base. ${ }^{75}$

He goes on to ask, then, "ought he not stand among you in bronze?" (Eĩ $\tau \alpha$

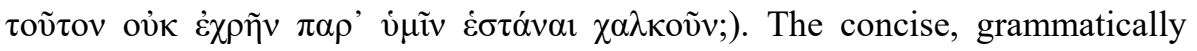
tacked on question interupts the long train of thought that has preceded it, interjecting itself like the material whose erection it proposes. The question is the

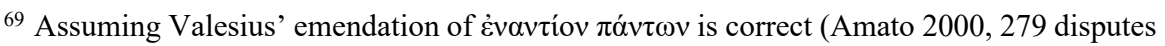
the need for any correction). The meaning is the same even without the appearance of the word "one."

70 This passage has become a locus classicus for the application of Bourdieu's concept of habitus to the self-fashioning of the Second Sophistic. See Gleason 1995, xii, xxiv; Schmitz 1997, esp., 26-31; and Porter 2006, 46.

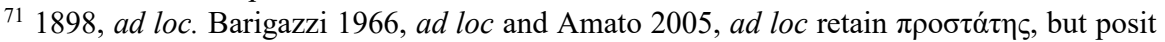
that the word refers to Hadrian.

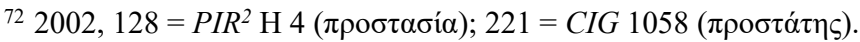

${ }^{73}$ Favorinus begins his conjuring act at the end of the speech by addressing his statue as his friend. See White 2003, 2005.

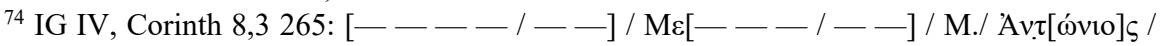

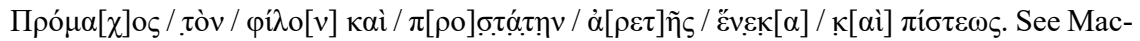
Gillivray 2011 for a discussion of $\pi \rho 0 \sigma \tau \alpha \dot{\tau} \tau \zeta$, including its use in euergetistic contexts.

${ }^{75}$ Including in the inscription quoted above. 
first of two instances in which Favorinus invokes the material statue as the logical

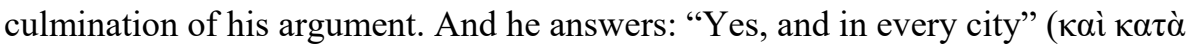
$\pi$ ó $\lambda \iota v \varepsilon$ ). In his uniqueness, he ought to stand in every polis. This is, of course, what it means to be a universal figure: to be a relevant model to any given constituency. ${ }^{76} \mathrm{He}$ will now go on to explain why this is the case. Here, the distribu-

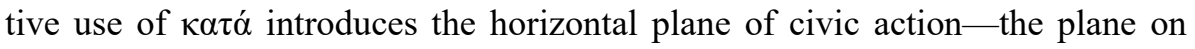
which the Corinthians enacted their historical role as protectors of democratic institutions. In the last section of the passage (27), Favorinus justifies his position on the vertical axis - the axis that connects him to the gods. After explaining his usefulness to various constituencies, he again invokes the statue: "for this very

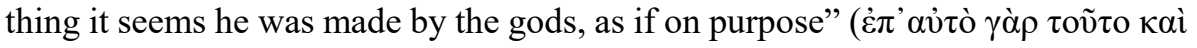

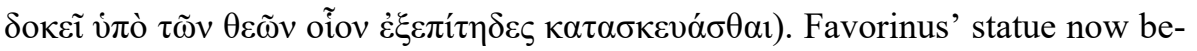
comes a product of the divine. ${ }^{77}$ As an embodiment of Greekness, Favorinus mediates between his audience and their Greekness; because the pursuit of Greekness is divinely prescribed, he, like a statue, mediates between the audience and the divine. He inspires others ( $\dot{\varepsilon} \pi \alpha i ́ p \omega)$, attracting ( $\dot{\varepsilon} \pi 1 \sigma \pi \alpha \dot{\alpha} \omega)$ even non-Greeks to this pursuit (26). Therefore, whereas heretofore he has emulated his ideal, he is now the object of emulation.

Again, he enumerates the purposes for which he was made. To the Greeks he is the $\pi \alpha \rho \alpha \dot{\alpha} \delta \varepsilon \gamma \mu \alpha$ - the sculptor's model ${ }^{78}$ - that "there is no difference between being educated and being born Greek, with respect to seeming/reputation" (ov̉ $\delta \dot{\varepsilon} v$

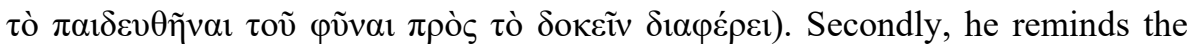
Romans not to overlook the role of paideia in achieving true honor. Finally, he is a beacon for the Celts, who should now be able to recognize the value of paideia,

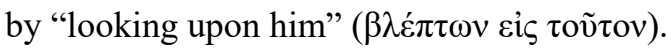

Favorinus has been speaking about a hypothetical man. But with this last phrase that hypothetical man emerges as a concrete presence. Through the eyes of "barbarians," these Hellenizing Romans ${ }^{79}$ look upon him and cannot fail to recognize the speaker's achievement. The speaker, who transcends any particular persona - statue, advocate - which has heretofore been introduced, stands before them as the embodiment of Greek paideia. And, once again, he proclaims,

${ }^{76} \mathrm{Cf}$. Stewart's 2006 discussion of imperial portraits, which he argues distributed the agency of the emperor across the empire, by " $\mathrm{g}[\mathrm{iving}]$ substance to his identity in solid representations" (244).

$77 \kappa \alpha \tau \alpha \sigma \kappa \varepsilon v a ́ \zeta \omega$ is often used to describe statue-making. Dio does so in his Rhodian Oration at $31.26,31.41$, and 31.57 .

${ }^{78}$ LSJ, s.v. I.1.

${ }^{79}$ Favorinus himself calls the city "Hellenized" (26). See Engels 1990, 71-74 on changes in the identification practices of the Corinthians dating from Hadrian's reign; but cf. König's 2001 reservations about Engels' reliance on material evidence. 


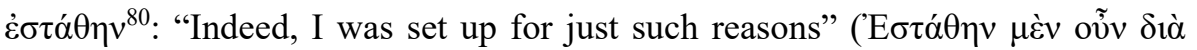

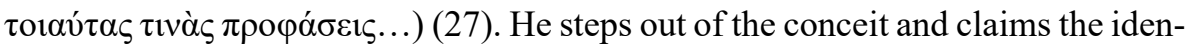
tity of the man he has been describing—oũ

Favorinus completes his argument by returning to the concept with which he opened the trial: the $\alpha v \alpha \dot{\theta} \theta \eta \mu \alpha$. If the erection of a statue is divinely ordained, he explains, then the putting up and the taking down thereof are not equal and opposite actions. Why? Favorinus ventures an explanation: "Because each one of those which you have put up ( $\tau \tilde{\omega} v \pi \alpha \rho$ '

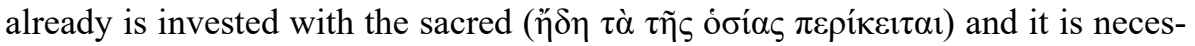

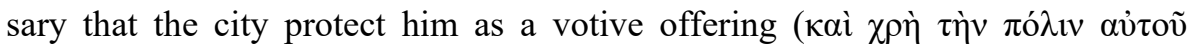
$\pi \rho 0 \varepsilon \sigma \tau \alpha \dot{v} v \alpha 1 \dot{\omega} \varsigma \dot{\alpha} v \alpha \theta \eta \dot{\mu} \mu \alpha \tau \rho \varsigma) "(28) .{ }^{81}$ Favorinus argues for a statue's sanctity by virtue of its placement. Once a statue his been erected, it is surrounded ( $\pi \varepsilon \rho i ́ \kappa \varepsilon i \tau \alpha l)$, and thus invested ( $\pi \varepsilon \rho i ́ \kappa \varepsilon \imath \tau \alpha l)$ with the sacred. Enmeshed in a network of sacred objects, its placement is fixed.

And now, it is the city's job to reciprocate and complete Favorinus' work. If Favorinus is the protector ( $\pi \rho \circ \sigma \tau \alpha \dot{\tau} \tau \varsigma)$ of Greekness, the city must "stand before so as to guard" ( $\pi \rho 0$ "ï $\tau \eta \mu \mathrm{l}$ ) the embodiment of this sacred work, as if he were an $\dot{\alpha} v \alpha \dot{\theta} \eta \eta \mu \alpha$ (28). His position now fixed, it is for them to assume their position with respect to him. And, of course, they are already arrayed around him. Their physical orientation ensures that the deontic is already accomplished. With their implicit affirmation of their role, Favorinus, statuary model ( $\pi \alpha \rho \alpha ́ \delta \varepsilon 1 \gamma \mu \alpha)$ of Greekness, becomes an $\dot{\alpha} v \alpha \dot{\theta} \theta \eta \mu \alpha$.

\section{For Love of Favorinus}

In the next sections (33-37), Favorinus moves from the sacred to the sexual. He offers an indirect defense against the unspecified charges that precipitated his statue's removal. But again he turns a vulnerability into an opportunity. An allusion to allegations of sexual impropriety allows him to connect his oratorical powers to his sexual virility.

He begins by listing the statues of great men and gods that have also been defiled. Even female deities (who should most be respected) are touched, denuded, and shown in sexual embrace (33). If these goddesses and the most famous

\footnotetext{
${ }^{80}$ See above on emendations of the first person of the verb.

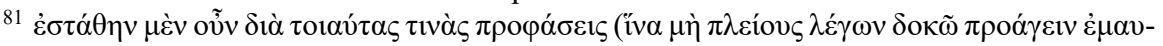

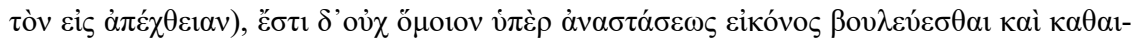

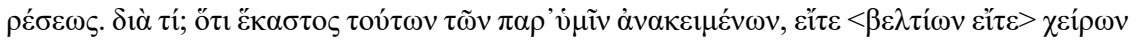

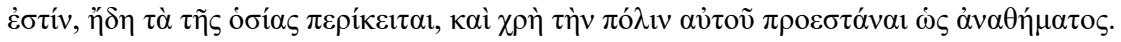


men are shown such disrespect, should it come as any surprise that this man has

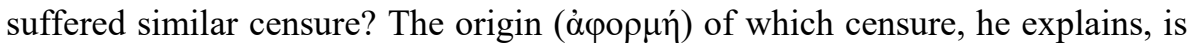
the loveliness ( $\left.\dot{\varepsilon} \pi \alpha \rho \rho \delta \delta \sigma^{\circ} \alpha\right)$ of his words, "or whatever it is appropriate to call this thing that you, your women, and your children approve of" (33). ${ }^{82} \mathrm{Here}$ Fa-

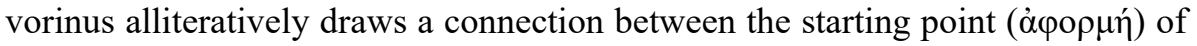
his disrepute and the pleasure ( $\dot{\varepsilon} \pi \alpha \varphi \rho o \delta 1 \sigma i \alpha)$ his oratory produces; aurally, the cause of the scandal and the pleasure the audience experiences ( $\dot{\varepsilon} \pi \alpha \varphi \rho \delta \delta 1 \sigma i \alpha)$ are co-extensive (perhaps this alliteration is an example of that pleasure).

His gloss of $\dot{\varepsilon} \pi \alpha \varphi \rho o \delta เ \sigma i \alpha$ as "whatever it is appropriate to call this thing that you, your women, and your children approve of" (33) might seem to absolve Favorinus of prurience - unless he is facing an especially permissive audience. Which, he suggests, he is. He asks his audience to consider whether they, who

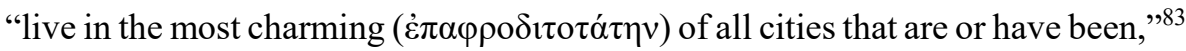

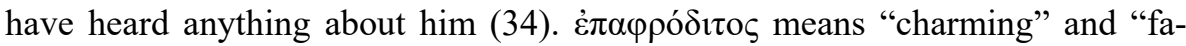
vored by Aphrodite," but the repetition of the root $\alpha \varphi \rho o \delta i \sigma 1 \alpha$ ("sexual pleasures") after غ̇ $\pi \alpha \varphi \rho o \delta ı \sigma i ́ \alpha$ just above introduces more explicit connotations. Corinth was famous for its cult to Aphrodite and had a reputation for sexual license. ${ }^{84}$ If Corinth, the hearth of Aphrodite, knows nothing of his exploits, they must not have occurred. Alternatively, if even their women and children were worshippers of the goddess ${ }^{85}$ and if they interpret Favorinus' "charm" otherwise, then they implicate

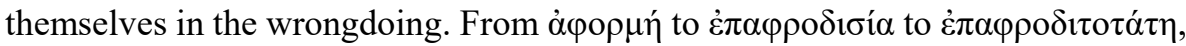
Favorinus imbues the city with the attribute he has been accused of possessing. It is the city, after all, that is superlatively charming. Whatever happened is bound up in the contingency of their reception of his words.

The trial now comes to an end. Favorinus chides Corinth for dishonoring the man whom others are welcoming wholeheartedly, whom others are honoring with

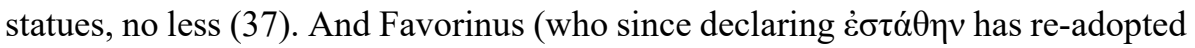
the voice of the advocate) resurfaces as the first-person speaker once and for all: "on behalf of myself and my statue I will now relate the phrase which Anaxagoras uttered when he lost his son, 'I knew I begat a mortal'..." (37). ${ }^{86}$

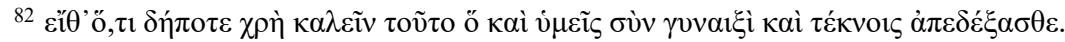

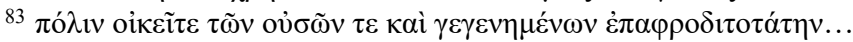

${ }^{84}$ See Engels 1990, 97-99. On the cult on Akrocorinth, see Williams 1986. Beard and Henderson 1998 and Lanci 2005 challenge the existence of cult prostitution.

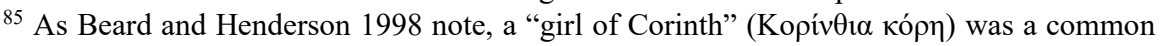

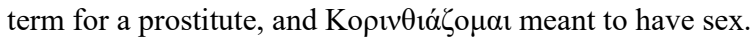

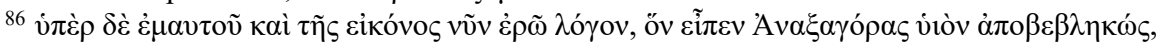

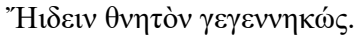




\section{Against Materiality}

The trial has accomplished a great deal. It has, first of all, established the rules of engagement within the performance. These rules assigned roles to the speaker and his audience and the roles were imbued with ethical import - the preservation of Greekness. At the heart of this act of preservation stands the recognition of Favorinus' paradigmatic status. At the same time, the trial addressed - obliquelythe accusations that brought his statues low. Just as the audience was fully implicated in the act of preservation, it is fully implicated here, in the incriminating deeds. The pleasure they take in his charming words cannot be disentangled from the sexual pleasure the Isthmus welcomes, and therefore, from whatever deed he himself may have committed.

Now, the frame of the trial is dismantled. In the last section of the speech,

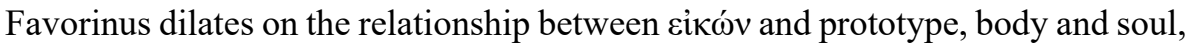
materiality and transcendence. He piles anecdote upon anecdote, in order, ultimately, to assert the ontological priority of the second term in each pair and the failure of the first.

He begins with the quote of Anaxagoras related just above: "I knew I begat a mortal..." (37). He admits that although honors are erected with the intention that they stand for all time, fate will inevitably (37-38) destroy the statue. As proof of the transience of bronze, he quotes the famous epitaph on Midas' grave: "I am a bronze maiden. I was placed on the grave of Midas. As long as the water flows and the trees grow tall, remaining here, at the much-mourned tomb of Midas, I will announce to those passing by that Midas is buried here" $(38) \cdot{ }^{87} \mathrm{He}$ concludes: while we still hear the poet's voice, no grave has been found, and though the waters flow and the trees still flourish, one day they too will disappear.

He then moves on to a less totalizing form of material impermanence: the appropriation of old statues for new subjects. ${ }^{88}$ In these cases, Greek statues are reinscribed to honor Roman men ( $\mu \varepsilon \tau \alpha \gamma \rho \alpha \varphi \eta)^{89}{ }^{89}$ The examples of material failure which he has enumerated lead to Favorinus' total rejection of the plastic artsand then of bodily form more generally: "Indeed, they say that even the body of

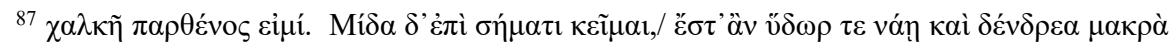

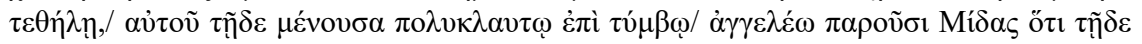
$\tau \dot{\varepsilon} \theta \alpha \pi \tau \alpha$.

${ }^{88}$ The topic of Dio Chrysostom's $31^{\text {st }}$ oration to the Rhodians, discussed above.

${ }^{89}$ As in the sections in which Favorinus discussed Corinth's role in Greek history, which, I argued, employed $\kappa \alpha \tau \alpha$-prefix words to mark the civic work he was describing, here Favorinus relies heavily on alliteration based on $\alpha v \alpha$-prefix words to mark the (perversion of the) dedication to the divine. 
nobles is foreign" (44). ${ }^{90}$ The last string of anecdotes chronicles the body's separation from the soul. Favorinus recounts the story told by Herodotus of Amasis providing a substitute corpse for Cambyses' posthumous abuses and another in which Anaxagoras, being ground down, proclaims that only that with which he was covered ( $\pi \varepsilon \rho \iota \kappa \varepsilon i ́ \mu \varepsilon v o \varsigma)$ was being destroyed (44-45). ${ }^{91}$ Anaxagoras himself, Favorinus avers, was not harmed. He brings us to the logical endpoint of the meditation: "Should I not allow the statue to be melted down, even if it perceives?" (46). ${ }^{92}$ In the same breath, therefore, he rejects his own speech's argument by suggesting that he allow the statue to perish — and he imbues it with life force.

\section{Resurrection}

Instead of capitulating to the preponderance of evidence he has just laid out, Favorinus pivots. He turns away from philosophy and argumentation and simply reorients himself with respect to the object under investigation. He turns to his statue - materially absent as it may be - and addresses it. Quoting Euripides' Laodameia, he proclaims his allegiance: "I would not betray even a soulless (ö $\psi v \chi 0 v)$ friend" (46) ${ }^{93} \mathrm{He}$ announces that he will address his statue directly, "as if he were sensate." And then apostrophizes: "Oh, silent image of my words, are

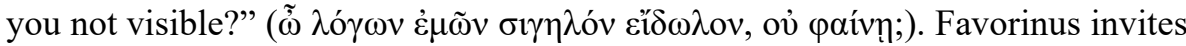
his audience to imagine his likeness in terms of its lack: it does not speak, and it is not manifest. It is an $\varepsilon i \delta \omega \lambda o v$, a problematic fiction that approximates the truth. ${ }^{94}$

He relates another Herodotean anecdote about the epic poet Aristeas' posthumous appearances. ${ }^{95}$ Favorinus asserts, "Aristeas lived then, now, and for all time" (46).$^{96}$ With this example of a man's ability to transcend his material form, he calls on two poets to corroborate the claim. First, Sappho: "someone will remember me, even in another time" (47).$^{97}$ Just as we still hear the voice of the

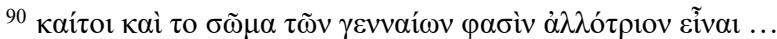

${ }^{91}$ Hdt. 3.16. See Steiner 2001, 126-129.

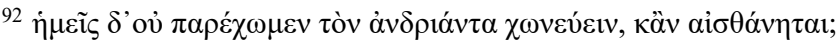

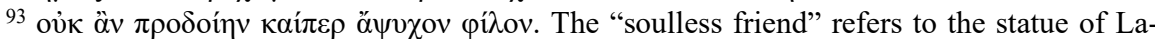
odameia's dead husband, Protesilaus, with whom Laodameia sleeps every night.

${ }^{94}$ Steiner 2001, 5. By this time $\varepsilon i \delta \omega \lambda$ ov could be used in a less contentious sense to mean "image of a god, idol" (LSJ, IV). See Amato ad loc.

${ }^{95}$ Hdt. 4.15-16. The anecdote ends with a report that the Metapontines set up a statue of Aristeas by the statue of Apollo, as Aristeas' apparition itself directed.

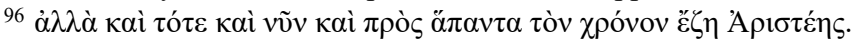

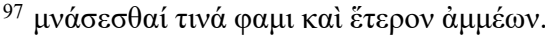


poet who inscribed Midas' statue, Sappho has achieved immortality in her song. He continues "more beautifully," with Hesiod: " $\varphi \eta \mu \eta$ does not completely die, which is spoken by many people. For she is also a god" (

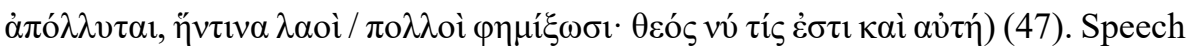
is divine. And so, Favorinus engages in a speech act of immortalization:

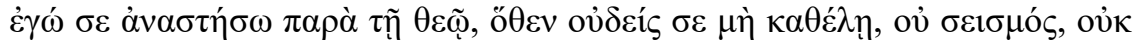

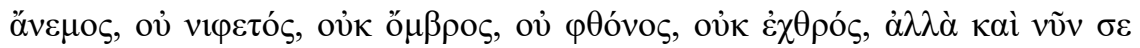

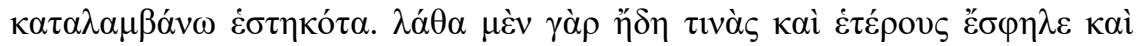

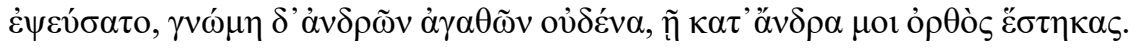

I will set you up by the god, where nothing will take you down, neither earthquake, nor wind, nor snow nor rain, nor envy nor hatred; but even now I find you standing. Already oblivion/forgetfulness has tripped some others and fooled them, but $\gamma v \omega ́ \mu \eta$ fools no good man, by which you stand upright as befits a man.

Without a transcript of the performance as a whole we cannot know how Favorinus orchestrated this final conjuring act. Maybe, as Crosby suggests, he was standing next to a veiled mass which only in this instant was uncovered to reveal a new statue. ${ }^{98}$ White argues that Favorinus gave the speech not only in the Corinthian forum in front of the library, but next to his empty pedestal. ${ }^{99}$ As Goggin suggests, this peroration probably constituted one of the odes for which Favorinus was famous, in which case he would already have broken out in song. ${ }^{100}$ If so, perhaps, with the melodic recitation of each potential threat, he made his way onto the stone base. And as the audience contemplates the distant ideal-the statue- $\mathrm{Fa}$ vorinus appropriates his posture by making himself upright (ỏ $\rho \theta$ ós) and claims to have already come upon it.

Whatever the reading, with $\kappa \alpha \tau \alpha \lambda \alpha \mu \beta \alpha \dot{\alpha} \omega \omega$ a purely rhetorical encounter (address) becomes physical. He comes upon his erected statue. The future ("I will put you up") becomes the present ("I find you standing"). Or, perhaps, here he grasps metaphorically, with the mind, what he has already accomplished: "I comprehend you standing." With another $\kappa \alpha \tau \alpha$-prefix verb, Favorinus reclaims his reality. The encounter on the horizontal and civic plane is, however, also oriented vertically. He uses an $\alpha v \alpha$-prefix verb ( $\alpha v i \sigma \tau \eta \mu \mathrm{l})$ to place the statue "by the god"

\footnotetext{
$981932,2$.

992005.

${ }^{100}$ Goggin 1951, 195. Philostr. VS 492.
} 


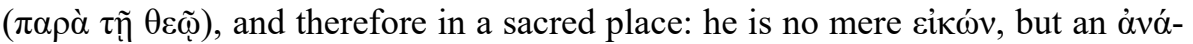
$\theta \eta \mu \alpha$ - a votive offering dedicated to the goddess $\varphi \eta \mu \eta$ — "fame," or, "rumor."101 Favorinus has dedicated himself to his own immortality - be that afterlife noble ("fame") or ignominious ("rumor"), as his adversaries would have it. And where no physical likeness stands, the audience finds only him, the orator, in flesh and blood, claiming to have subsumed all the power of the symbol by his mere presence. What was initially prototype and likeness is now one entity.

But, as always, the audience must affirm his successful transformation. He makes his expectations clear: "Oblivion has already tripped up some others and cheated them, but $\gamma v \omega ́ \mu \eta$ (trips up and cheats) no good man, by which you stand upright (ỏ $\theta$ óc) as befits a man." ${ }^{\prime 102}$ There is an ambiguity in this passage. Has $\lambda \dot{\alpha} \theta \alpha$ tripped up other (Ë $\varepsilon \varepsilon \rho o$ ) statues? The men those statues represent? Or the men whose forgetfulness allows them to topple statues? In the clause $\gamma v \omega \dot{\mu} \mu \eta \delta^{\prime} \dot{\alpha} v-$

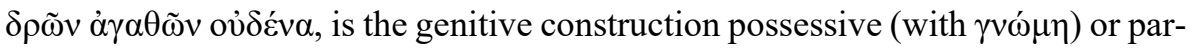

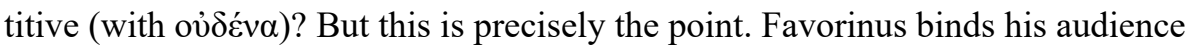
up in the syntactical circularity of the clause: the judgement of good men trips up no good man. Just as his sense of reality was contingent on his audience in the beginning of the speech, here, the nobility of the audience, the men they honor in bronze, and his own are completely intertwined. And their $\gamma v \omega ́ \mu \eta$ is not only aesthetic and juridical, it is performative: because of their right judgment ( $\tilde{\mathfrak{n}})$, his statue stands. ${ }^{103}$ As he speaks ỏ $\theta$ ó, , upright, they resurrect him. Moreover, $\kappa \alpha \tau^{\prime}$ 'ö $v \delta \rho \alpha$ might also be understood distributively: ${ }^{104}$ you stand upright for me in every man. Just as he deserves to be erected in every city, he is already erected in the minds of each individual spectator. Here, perhaps, he modulated his voicehere, where he claims, not his Greekness, but his manhood. If Polemo has accused Favorinus of being unable to walk upright, Favorinus now proves him woefully short-sighted. The eunuch stands erect and his upright posture becomes an icon

${ }^{101}$ In Dio's appeal to the Rhodians he argues that statues ( $\left.\dot{\alpha} v \delta \rho \alpha^{\prime} v \tau \varepsilon \varsigma\right)$ put up in sacred places are votive offerings $\dot{\alpha} v \alpha \theta \eta \dot{\eta} \mu \alpha \tau \alpha$ (31.89). He justifies this "reading" with reference to in-

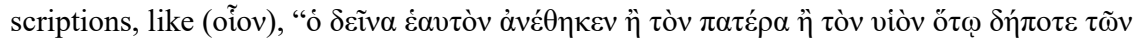
$\theta \varepsilon \tilde{\omega} v$." See Ma 2013, 79-85 and Keesling 2017, 81-149 on honorific statues set up in shrines and sanctuaries. Cf. Price 1983, 178-179 and Koonce 1988 on distinguishing $\alpha \gamma \alpha \dot{\alpha} \lambda-$

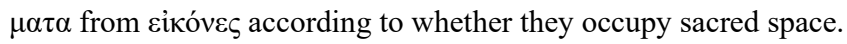

102 Philostratus VS 519 tells us that Herodes considered Polemo a particularly effective

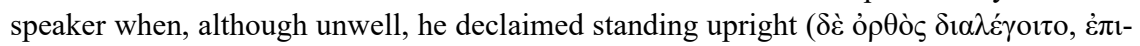

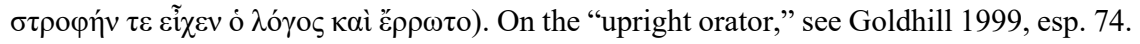

${ }^{103} \gamma v \omega \dot{\mu \eta}$ has similar performative force in his On Exile, where Favorinus uses it to make himself a citizen of Chios (14.1-2).

104 This is how Barigazzi 1966 ad loc takes $\kappa \alpha \tau$ ' $\alpha \nu \delta \rho \alpha$ : "in ogni singolo uomo." 
of his virility. If seeming to be Greek trumps all else, his orientation is-seemingly, at least—absolute. ${ }^{105}$

\section{Bibliography}

Ahmed, S. 2006. Queer Phenomenology, Durham - London: Duke UP.

Amato, E. 2005. Favorinos d' Arles: Oeuvres, Paris: Belles Lettres.

— 2000a. "Favorino: Sul 'proprio' Esilio," Zeitschrift für Papyrologie und Epigraphik, Bd. $133,43-50$.

- 2000b. "Adversaria critica in Favorinum Arelatensem," Latinitas 48, 4, 275-287.

Arnim, H. von. 1898. Leben und Werke des Dion von Prusa, Berlin: Weidmann.

Favorinus \& Barigazzi, A. 1966. Opere: introduzione, testo critico e commento, a cura di Adelmo Barigazzi. Firenze: Le Monnier.

Barton, T. 1994. Power and Knowledge: Astrology, Physiognomics, and Medicine under the Roman Empire. Ann Arbor: University of Michigan Press.

Beard, M. and J. Henderson. 1998. "With This Body I Thee Worship: Sacred Prostitution in Antiquity," in: M. Wyke (ed.), Gender and the Body in the Ancient Mediterranean, Oxford and Malden: Blackwell.

Beall, S. M. 2001. "Homo Fandi Dulcissimus: The Role of Favorinus in the 'Attic Nights' of Aulus Gellius," The American Journal of Philology 122, 1, Spring, 87-106.

Blanck, H. 1969. Wiederverwendung alter Statuen als Ehrendenkmäler bei Griechen und Römern, Roma: L'Erma di Bretschneider.

Borg, B. 2004. "Glamorous Intellectuals: Portraits of Pepaideumenoi in the Second and Third centuries AD," in: B. Borg (ed.), Paideia: The World of the Second Sophistic. Berlin: Walter de Gruyter.

Bowersock, G. W. 1969. Greek Sophists in the Roman Empire. Oxford: Oxford UP.

Bowie, E. L. 2004. "The Geography of the Second Sophistic," in: B. Borg (ed.), Paideia: The World of the Second Sophistic. Berlin: Walter de Gruyter, 65-83.

— 1997. 'Hadrian, Favorinus, and Plutarch," in: J. Mossman (ed), Plutarch and His Intellectual World: Essays on Plutarch, London: Duckworth, 1-16.

- 1970. "Greeks and their Past in the Second Sophistic," Past and Present 46, Feb, 3-4.

Breckenridge, J. D. 1968. Likeness: A Conceptual History of Ancient Portraiture. Evanston: Northwestern University Press.

Brown, A. 2012. "Last Men Standing: Chlamydatus Portraits and Public Life in Late Antique Corinth," Hesperia, 81, 1, Jan.-March, 141-176.

Cavarero, A. 2016. Inclinations: A Critique of Rectitude. A. Minervini \& A. Sitze, trans. Stanford: Stanford UP.

Crosby, H. L., trans. 1932. Dio Chrysostom, vol. IV, Cambridge: Harvard UP.

${ }^{105}$ I am grateful to Susan Stephens who patiently read multiple drafts of this article and to Maud Gleason - their insights and encouragements have been integral to this project's development. I am deeply indebted to the reviewers whose extensive and generous comments improved the argument immeasurably. I was unable to fully incorporate all of their suggestions: omissions and mistakes are my own. This article is dedicated to the memory of my father, Harry Brod, and his work. 
Dillon, S. 2006. Ancient Greek Portrait Sculpture: Contexts, Subjects, and Styles, Cambridge: Cambridge UP.

Elsner, J. 2007. "Physiognomics: Art and Text, in: S. Swain (ed.), Seeing the Face, Seeing the Soul: Polemon's Physiognomy from Classical Antiquity to Medieval Islam, Oxford: Oxford UP, 203-224.

Engels, D. W. 1990. Roman Corinth: An Alternative Model for the Classical City, Chicago: U of Chicago Press.

Feher, M., Naddaff, R., \& Tazi, N. 1989. Fragments for a History of the Human Body, New York, N.Y.: Zone.

Fein, S. 1994. Die Beziehungen der Kaiser Trajan und Hadrian zu den Litterati, Stuttgart Leipzig: De Gruyter.

Fisher, N. R. E \& Wees, H. van. (eds.), Competition in the Ancient World, Swansea: Classical Press of Wales.

Förster, R. (ed.). 1893. Scriptores Physiognomonici Graeci et Latini, vol. 1, Leipzig.

Gleason, M. 1995. Making Men, Princeton: Princeton UP.

Goeken, J. 2005. "L'histoire de Corinthe dans la Rhétorique Grecque de l'Empire Romain," Cahiers des Études Anciennes 42, 327-351.

Goggin, M. 1951. "Rhythm in the Prose of Favorinus," Yale Classical Studies 12, 149-201.

Goldhill, S. 1999. "Literary History without Literature: Reading Practices in the Ancient World," SubStance 28, 1, 88, 57-89.

Gunderson, E. 1998. "Discovering the Body in Roman Oratory," in: M. Wyke, (ed.), Parchments of Gender: Deciphering the Bodies of Antiquity, NY: Oxford UP, 169-189

Hermary, A. 1994. "Les Noms de la Statue chez Herodote," in: C. Vatin, M. Amouretti, and P. Villard (eds.), EYKPATA: Mélanges Offerts à Claude Vatin, Aix-en-Provence: Université de Provence, 21-29.

Højte, J. M. 2002. "Cultural Inter-change? The Case of Honorary Statues in Greece," in: E.N. Ostenfeld and K. Blomqvist (eds.), Greek Romans and Roman Greeks: Studies in Cultural Interaction, Aarhus: Aarhus UP, 55-63.

Holford-Strevens, L. 2003. Aulus Gellius: An Antonine Scholar and his Achievement, Oxford: Oxford UP.

— 1997. "Favorinus: The Man of Paradoxes," in: J. Barnes and M. Griffin (eds.), Philosophia Togata II: Plato and Aristotle at Rome, Oxford: Clarendon Press, 188-217.

Holmes, B. 2010. The Symptom and the Subject: The Emergence of the Physical Body in Ancient Greece. Princeton: Princeton UP

Hoyland, R. (trans.). 2007. "A New Edition and Translation of the Leiden Polemon," in: S. Swain (ed.), Seeing the Face, Seeing the Soul: Polemon's Physiognomy from Classical Antiquity to Medieval Islam, Oxford: Oxford UP, 329-463.

Ioppolo, A. 1993. "The Academic Position of Favorinus of Arelate," Phronesis 38, 2, 183-213.

Jones, C.P. 1978. The Roman World of Dio Chrysostom. Cambridge: Harvard UP.

Keesling, C. M. 2017. Early Greek Portraiture: Monuments and Histories, Cambridge: Cambridge UP.

- 2003. The Votive Statues of the Athenian Acropolis, Cambridge: Cambridge UP.

König, J. 2011. "Competitiveness and Anti-Competitiveness in Philostratus' Lives of the Sophists," in: N. R. E Fisher \& H. van. Wees (eds.), Competition in the Ancient World, Swansea: Classical Press of Wales.

- 2001. "Favorinus' Corinthian Oration in its Corinthian Context," Proceedings of the Cambridge Philological Society 47, 141-171.

Koonce, K. 1988. “Agalma and Eikwn.” American Journal of Philology 109, 1, 108-110. 
Kurke, L. 1993. "The Economy of Kudos," in: C. Dougherty and L. Kurke (eds.), Cultural Poetics in Archaic Greece: Cult, Performance, Politics, New York: Cambridge UP.

Kyle, D. G. 1998. Spectacles of Death in Ancient Rome, London: Routledge.

Lakoff, G. and Johnson M. 1980. Metaphors We Live By, Chicago: U of Chicago P.

Lanci J. R. 2005. "The Stones Don't Speak and the Texts Tell Lies: Sacred Sex at Corinth,” in: D.N. Schowalter and S.J. Friesen (eds.), Urban Religion in Roman Corinth: Interdisciplinary Approaches, Cambridge: Harvard Theological Studies, 205-220.

Lattanzi, G.M. 1933. "La Figura di Favorino d'Arelate e due orationi contestate di Dione Crisostomo," Rivista di Filologia e di Istruzione Classica, 44-57.

Lazzarini, M.L. 1989-1990. "Iscrizioni votive greche," ScAnt 3-4, 845-859.

- 1984-1985. "Epigrafia e Statua Ritratto: Alcuni Problemi," AAPat 97, 83-103.

Ma, J. 2013. Statues and Cities: Honorific Portraits and Civic Identity in the Hellenistic World, Oxford: Oxford UP.

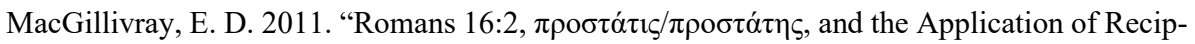
rocal Relationships to New Testament Texts," Novum Testamentum 52, 2, 183-199.

Mason, H. J. 1979. “Favorinus' Disorder: Reifenstein's Syndrome in Antiquity?” Janus 66, 113.

Nesselrath, H. 2006. "Later Greek Voices on the Predicament of Exile," in: J. F. Gaertner (ed.), Writing Exile, Leiden and Boston: Brill, 87-108.

Nodelman, S. 1975. "How to Read a Roman Portrait," Art in America 63, 27-33.

Opsomer, J. 1997. "Favorinus versus Epictetus on the Philosophical Heritage of Plutarch: A debate on Epistemology," in: J. Mossman (ed.), Plutarch and His Intellectual World: Essays on Plutarch, London: Duckworth, 17-40.

O'Sullivan, T. 2016. "Human and Asinine Postures in Apuleius' Golden Ass," Classical Journal 112, 2, 196-216.

Peirce, C.S. 1955 [1940]. Philosophical Writings. New York: Dover.

Puech, B. 2002. Orateurs et sophistes grecs dans les inscriptions d'epoque impériale, Paris: Librairie philosophique J. Vrin.

- 1992. "Prosopographie des amis de Plutarch," ANRW II, 33, 6, 4831-4893.

Platt, V. 2011. Facing the Gods: Epiphany and Representation in Graeco-Roman Art, Literature and Religion, Cambridge, UK: Cambridge University Press.

- 2007. "'Honor takes Wing': Unstable Images and Anxious Orators in the Greek Tradition," in: Z. Newby \& R. E. Leader-Newby (eds.), Art and Inscriptions in the Ancient World, Cambridge: Cambridge UP, 247-271.

Porter, J. I. 2006. "Introduction: What is 'Classical' about Antiquity?" in: J. I. Porter (ed.), Classical Pasts: The Classical Tradition of Greece and Rome. Princeton: Princeton UP. 165.

Price, S. R. F. 1983. Rituals and Power: Roman Imperial Cult in Asia Minor. Cambridge: Cambridge UP

Repath, I. (trans.) 2007a. "The Physiognomy of Adamantius the Sophist," in: S. Swain (ed.), Seeing the Face, Seeing the Soul: Polemon's Physiognomy from Classical Antiquity to Medieval Islam, Oxford: Oxford UP, 487-547.

- (trans.) 2007b "Anonymus Latinus, Book of Physiognomy," in: S. Swain (ed.), Seeing the Face, Seeing the Soul: Polemon's Physiognomy from Classical Antiquity to Medieval Islam, Oxford: Oxford UP, 549-635.

Richter, G. M. A. 1965. The Portraits of the Greeks, vol.1 and 3., London: Phaidon Press.

Rimell, V. 2017. "Philosophy's Folds: Seneca, Cavarero, and the History of Rectitude," Hypatia $32,4,768-783$. 
Romilly, J. de. 1975. Magic and Rhetoric in Ancient Greece, Cambridge: Harvard UP.

Schmid, W. 1909. "Favorinus," in: Realencyklopädie, VI, 2078-2084.

Schmitz, T. 1997. Bildung und Macht: zur sozialen und politischen Funktion der zweiten Sophistik in der griechischen Welt der Kaiserzeit, München: Verlag C.H. Beck.

Shear, J. 2007. "Reusing statues, rewriting inscriptions and bestowing honors in Roman Athens," in Z. Newby \& R. E. Leader-Newby (eds.), Art and Inscriptions in the Ancient World. Cambridge: Cambridge UP, 221-246.

Smith, R. R. R. 1998. "Cultural Choice and Political Identity in Honorific Portrait Statues in the Greek East in the Second Century A.D.," The Journal of Roman Studies 88, 56-93.

Steiner, D. 2001. Images in Mind: Statues in Archaic and Classical Greek Literature and Thought, Princeton: Princeton UP.

Stevenson, W. 1995. "The Rise of Eunuchs in Greco-Roman Antiquity," Journal of the History of Sexuality 5, 4, 495-511.

Stewart, P. 2006. "The Image of the Roman Emperor," in: R. Shepherd and R. Maniura (eds.), Presence: The Inherence of the Prototype within Images and Other Objects, Burlington: Ashgate, 243-258.

- 2003. Statues in Roman Society: Representation and Response. Oxford: Oxford UP.

Straus, E. W. 1966. “The Upright Posture,” Phenonmenological Psychology, trans. E. Eng, New York: Basic Books, 137-165.

Swain, S. (ed.). 2007. Seeing the Face, Seeing the Soul: Polemon's Physiognomy from Classical Antiquity to Medieval Islam, Oxford: Oxford UP.

- 1989. "Favorinus and Hadrian," Zeitschrift für Papyrologie und Epigraphik, Bd. 79, 150158.

van Straten, F. 1992. "Votives ad Votaries in Greek Sanctuaries," Entretiens sur l' Antiquité classique 37, 247-284.

Varner, E. 2004. Mutilation and Transformation: Damnatio Memoriae and Roman Imperial Portraiture, Leiden: Brill.

Vernant, P. 1989. “Dim Body, Dazzling Body," in: M. Feher, R. Naddaff, \& N. Tazi, Fragments for a History of the Human Body. New York, N.Y.: Zone, 18-47.

Vitanza, V. J. 2005. "Favorinus," in: M. Ballif and M. Moran (eds.), Classical Rhetorics and Rhetoricians: Critical Studies and Sources, London: Praeger, 158-162.

White, M. 2003. "Rhetoric and Reality in Galatians," in: J.T. Fitzgerald and T.H. Olbricht (eds.), Early Christianity and Classical Culture, Boston - Leiden: Brill, 307-349.

- 2005. "Favorinus's 'Corinthian Oration': A Piqued Panorama of the Hadrianic Forum," in: D.N. Schowalter and S.J. Friesen (eds.), Urban Religion in Roman Corinth: Interdisciplinary Approaches, Cambridge: Harvard Theological Studies, 61-110.

Whitmarsh, T. 2001. Greek Literature and the Roman Empire: The Politics of Imitation, Oxford: Oxford UP.

Williams, C.K. 1986. "Corinth and the Cult of Aphrodite," in: M.A. Del Chiaro (ed.), Corinthiaca: Studies in Honor of Darrell A. Amyx, Columbia: U of Missouri Press, 12-24.

Wright, W. C., trans. 1989. Philostratus and Eunapius: The Lives of the Sophists, Cambridge: Harvard UP.

Zornberg, A. Gottlieb. 1996. The Beginning of Desire: Reflections on Genesis, New York: Doubleday. 